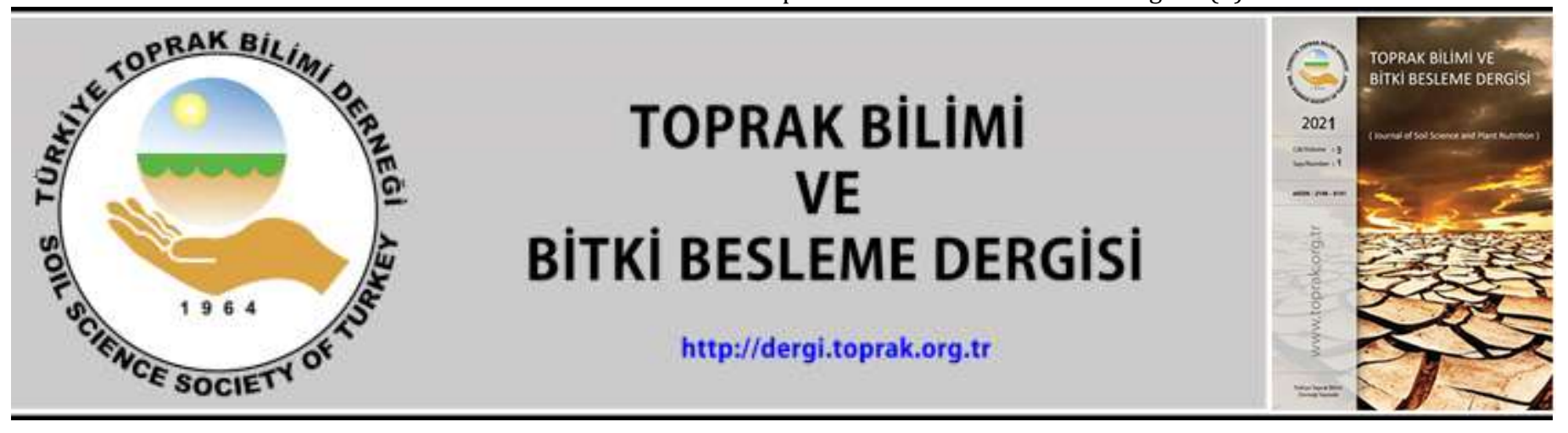

\title{
Ordu ve Giresun illerindeki fındık bahçelerinin toprak özellikleri ile biyolojik özellikleri arasındaki ilişkiler
}

\section{(D)Abdurrahman Ay* (D)Ridvan Kizılkaya}

${ }^{1}$ Ondokuz Mayıs Üniversitesi Ziraat Fakültesi Toprak Bilimi ve Bitki Besleme Bölümü Atakum-Samsun

\begin{abstract}
Özet
Çalışmada, Ordu ve Giresun illerinde fındık yetiştiriciliği yapılan alanlardan alınan toprakların biyolojik özellikleri ile bazı fizikokimyasal özellikleri arasındaki ilişkiler değerlendirilmiştir. Elde edilen sonuçlara göre; Ordu ve Giresun yöresinde fındık yetiştirilen topraklar genel olarak; orta bünyeli, asidik reaksiyonlu, tuzsuz, kireçsiz ve yeterli organik madde içeriğine sahiptir. Bununla birlikte, toprakların biyolojik özelliklerinden toprak solunumu, mikrobiyal biyomas C, dehidrogenaz ve katalaz enzim aktivitesi ile toprakların diğer özellikleri arasındaki ilişsiler araștırılmış, elde edilen sonuçlara göre, toprak biyolojik özelliklerini en fazla etkileyen toprak özelliğinin $\mathrm{pH}$, kireç ve organik madde olduğu belirlenmiştir. Toprak biyolojik özellikleri ile toprak organik madde kapsamı ve $\mathrm{pH}$ arasında önemli pozitif korelasyonlar belirlenmiştir. Analiz sonuçları yöre topraklarının en temel sorunu olan düşük $\mathrm{pH}$ değerlerinin optimum düzeye getirilmesi için gerekli uygulamaların yapılması besin elementlerinin alınmasının yanı sıra toprakların biyolojik özellikleri üzerine de olumlu etkiler yapacağını ortaya koymaktadır. Genel olarak toprakların organik madde seviyesi yapılan çalışmada yeterli seviyede olmasına rağmen organik madde içeriğinin toprakların sürdürülebilirliği, toprak kalitesi ve canlılığı açısından çok önemli bir parametre olduğu için muhafaza edilmesi gerekli görülmektedir.
\end{abstract}

Anahtar Kelimeler: Findık, Toprak solunumu, mikrobiyal biyomas C, dehidrogenaz, katalaz.

\section{Relationships Between Soil Properties and Biological Properties of Hazelnut Orchards in Ordu and Giresun Provinces}

\begin{abstract}
In this study, the physico-chemical and biological properties of soils taken from hazelnut cultivation areas in the provinces of Ordu and Giresun were determined and the relationships between the biological properties and the physico-chemical properties of soils were evaluated. Most of the soil samples taken from hazelnut grown areas in Ordu and Giresun region have fine textural class, acidic reaction, non-saline, low lime content, sufficient organic matter content. Biological properties of soils, soil respiration, microbial biomass C, dehydrogenase and catalase activity and other physico-chemical properties of soil between relationship investigated. According to the results, it was determined that the soil properties that affect the soil biological properties are the most important $\mathrm{pH}$, lime and organic matter. Significant positive correlations between soil organic matter content and pH were determined. As a result, it is thought that the applications to eliminate the acidity in the region will have positive effects on the biological properties of soils as well as the intake of nutrients. Although the organic matter level of the soils is sufficient in the study, it is necessary to conservation the organic matter content as an important parameter in terms of soil sustainability, soil quality and viability.
\end{abstract}

Keywords: Hazelnut, soil respiration, microbial Biomass C, dehydrogenase, catalase.

(C) 2021 Türkiye Toprak Bilimi Derneği. Her Hakkı Saklıdır

\section{Giriș}

Fındık (Corylus avelana) kışın yaprak döken çalılar ve ağaçlar olarak bilinen Corylus cinsi bitkiler kapsamında değerlendirilen; bodur ve çalı formunda olan uzun ömürlü bir bitkidir (Özbek, 1978; Köksal, 2002). Fındık bademden sonra dünyada en yaygın yetiştiriciliği yapılan sert kabuklu bir meyvedir. Fındık yetiştiriciliğinin yapıldığı başlıca ülkeler; Türkiye ilk sırada olmak üzere İtalya, İspanya, ABD, Gürcistan, Azerbaycan, Çin, İran, Şili, Avustralya ve Fransa'dır. Dünya fındık üretimi, 1960’lı yıllarda yaklaşık olarak 250 bin ton iken, son yıllarda bir milyon tona yaklaşmıștır. Dünyada findık tarımı 950 bin hektarlık alanda yapılmakta ve bu alanın yaklaşık 700 bin hektarı Türkiye' de bulunmaktadır (Anonim, 2017).

\section{* Sorumlu yazar:}

Tel. : : 0 (533) 4647888

E-posta : abdurrahman.ay@omu.edu.tr
Geliș Tarihi

Kabul Tarihi
20 Mayıs 2021

15 Haziran 2021
e-ISSN : 2146-8141

DOI : $10.33409 /$ tbbbd.940159 
Orta ve Doğu Karadeniz Bölgesi fındık yetiştiriciliğinde ortalama 400 bin hektarlık üretim alanıyla, toplam alanın yaklaşık \%70'ini kapsamaktadır. Bölgede yer alan iller içerisinde en fazla fındık dikim alanına \%32 ile Ordu, bunu sırasıyla \%17 Giresun ve \%9 Trabzon illeri takip etmektedir (TUİK, 2014). Ülkemizde fındık üretim alanları ve miktarı yüksek olmasına karşın, birim alandan elde edilen toplam ürün miktarı diğer ülkelerle kıyaslandığında verimi oldukça düşüktür (Özkutlu ve ark., 2016).

Fındık bitkisi saçak köke sahip bir kültür bitkisi olduğundan dolayı fazla derine gitmemekle birlikte, eğimli arazilerde $80 \mathrm{~cm}$ derinliğe kadar ulaşabilmektedir. Toprak isteği olarak fazla seçici değildir fakat toprak pH'sı 6 civarında olan, besin maddelerince zengin, tınlı-humuslu bünyeye sahip ve nispeten daha derin topraklarda daha iyi bir gelişme göstermektedir (Karadeniz ve ark., 2008). İklim, sulama, gübreleme, kültürel uygulamalar, toprak kalitesi gibi birçok faktörün etkili olduğu tarımsal verimlilik çok yönlü şartların optimum oluşması ile sağlanmaktadır. Özellikle kültürel uygulamaların asgari seviyede yapıldığı fındık yetiştiriciliğinde, tarımsal uygulamaların önemi bir kat daha artmaktadır. Ayrıca son yıllarda ülkemizde fındığın tarımsal ürün niteliğinin dışında gıda sanayisine hammadde oluşturması ve katma değerli ürünlere dönüştürülmesi büyük öneme sahiptir. Dörtte üç üretimi ülkemizde gerçekleştirilen bu ürünün verimlilik ve kalite açısından en yüksek değerlere sahip olması da yine ülkemiz tarımsal üretiminden beklenmelidir. Ülkemizin önemli bir ihracat ürünü olan fındığın, verimlilik ve kalite değerlerinin artırılması bölge üreticisinin ekonomik ihtiyaçlarını karşılaması açısından da hayati öneme sahiptir.

Fındık tarımında süreklilik ve verim artışı sağlamak amacıyla birçok çalışma yapılmıştır. Toprakların verimliliğinin artırılmasına yönelik olarak yapılan çalışmalarda genellikle toprakların fiziksel ve kimyasal özellikleri belirlenmekte olup, bu özelikler arasındaki ilişkiler dikkate alınmaktadır. Ancak, topraklarda fiziksel ve kimyasal değişimlerin meydana gelmesi ve bu değişimlerin saptanması uzun zaman alabilmektedir. Buna karşın, biyolojik ve biyokimyasal değişiklikler toprak içerisinde meydana gelen küçük değişikliklere (bozulma ve erozyon) bile çok hassas olduğu için kısa sürede tespit edilebilmektedir. Sonuç olarak toprak mikrobiyal aktivitesi ekosistemin dengesi ve verimliliği üzerinde doğrudan bir etkiye sahip olduğu için toprağın kalitesi hakkında çok doğru ve hızlı bilgiler verir (Smith ve Papendick 1993). Ayrıca, toprakların fiziksel ve kimyasal özelliklerinin mikrobiyal biyokütle ve mikrobiyal aktivite ile etkileşim içerisinde olduğu yapılan birçok çalışmada bildirilmiştir (Parr ve Papendick 1997; Karaca ve ark., 1998; Kizllkaya ve ark., 1998; Matson ve ark., 1999; Phoenix ve ark., 2006; Lu ve ark., 2010; Cusack ve ark., 2011; Durmuş ve ark., 2011; Kizılkaya ve ark., 2019).

Fındık tarımı, üretici özellikleri ve tarımsal üretim uygulamaları yönünden çok çeşitli ve büyük sorunlara sahiptir. Fakat, verimlilik parametrelerinin bir bütün olarak ortaya koyulması findık tarımında bulunan sorunların hızlı bir şekilde tespit edilmesini ve bu sorunların çözümüne katkılar sağlayacağı düşünülmektedir. Bu çalışmada, ülkemiz fındık üretim alanlarının yaklaşık olarak \%40'nın yer aldığı Ordu ve Giresun illerinde farklı konum ve topoğrafik özelliklere sahip fındık bahçesi topraklarının biyolojik özelliklerinin belirlenmesi ve bu özelliklerin bazı toprak özellikleriyle olan ilişkilerinin saptanması amaçlanmıştır.

\section{Materyal ve Yöntem}

Bu çalışma, Ordu ve Giresun ilinde fındık tarımı yapılan farklı konum ve topoğrafik özelliklere sahip 31 farklı bahçeden alınan toplam 62 adet toprak örneğinde yürütülmüştür. Toprak örneklerinin alındıkları noktalar Şekil 1'de verilmiştir. Toprak örnekleri, toprakların fiziko-kimyasal özellikleri ile biyolojik özelliklerinin belirlenmesi amacıyla fındık hasatını takiben 0-20 cm derinlikten Jones (2001) tarafından bildirildiği şekilde alınmıştır.

Toprakların bazı fiziko-kimyasal özelliklerini belirlemek amacıyla yaklaşık 2 kg toprak örneği alınmış, gölgede kurutulmuş, hava kuru hale gelen topraklar tahta tokmak ile dövülerek $2 \mathrm{~mm}$ 'lik elekten elenmiş, analizlere hazır hale getirilmiş ve laboratuvar koşullarında analizler için bekletilmiştir. Toprakların biyolojik özelliklerinin belirlenmesi için alınan taze toprak örnekleri araç buzdolabında $\left(+4^{\circ} \mathrm{C}\right)$ laboratuvara nakledilmiş, $2 \mathrm{~mm}$ 'lik elekten elenmiş ve analiz sırası gelinceye değin laboratuvarda buzdolabında $\left(+4^{\circ} \mathrm{C}\right)$ bekletilmiştir.

Alınan toprak örneklerinin; kil, silt ve kum fraksiyonları hidrometre yöntemi ile, toprak reaksiyonu (pH) 1:1 (w/v) toprak : saf su karışımında pH-metre ile, Elektriksel İletkenlik (EC) 1:1 (w/v) toprak : saf su karışımında EC-metre ile, organik madde kapsamı Walkey-Black yöntemi ile, kireç kapsamı $\left(\mathrm{CaCO}_{3}\right)$ Scheibler kalsimetresi ile volümetrik olarak belirlenmiștir (Rowell, 1996). 
Alınan toprak örneklerinde, toprakların biyolojik analizleri 3 paralelli olarak yapılmış ve tüm sonuçlar, toprakların nem içeriklerindeki farklılıklar dikkate alınarak kuru toprak cinsinden ifade edilmiştir. Toprak örneklerinin karbondioksit üretim miktarları Anderson (1982) tarafından bildirildiği şekli ile, mikrobiyal biyomas karbon içerikleri Anderson ve Domsch (1978) tarafından bildirilen substrat indirgenme yöntemine göre, dehidrogenaz enzim aktiviteleri Pepper ve ark. (1995) tarafından bildirildiği şekli ile ve katalaz enzim aktiviteleri ise Beck (1971) tarafından bildirildiği şekli ile belirlenmiştir.

Toprakların fiziksel, kimyasal ve biyolojik özelliklerinin istatistiksel olarak değerlendirilmesinde yapılan Pearson korelasyonu ile regresyon analizlerinde SPSS 17.0 paket programı kullanılmış, elde edilen sonuçlar Yurtsever (1984) tarafından bildirildiği șekli ile değerlendirilmiştir.

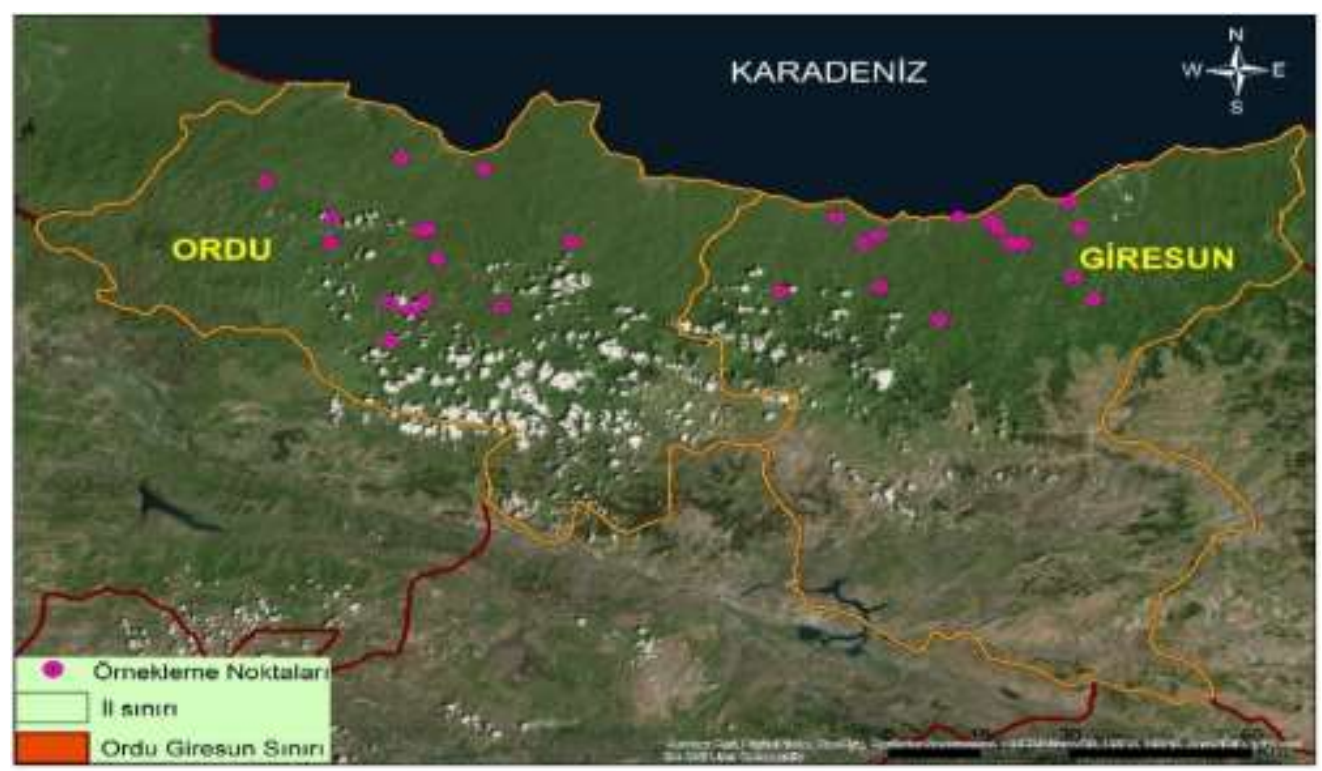

Şekil 1. Toprak örneklerinin alındığı noktalar

\section{Bulgular ve Tartışma}

Ordu ve Giresun illerinde bulunan fındık bahçelerinden alınan toprak örneklerinin tekstür sınıfları, pH, EC, organik madde ve kireç içeriklerine ait analiz sonuçları Çizelge 1'de verilmiştir.

Çizelge 1. Toprakların tekstür sınıfına göre gruplandırılması

\begin{tabular}{ccccccc}
\hline \multirow{2}{*}{ Tekstür sınıfı } & \multicolumn{2}{c}{ Ordu (n=32) } & \multicolumn{2}{c}{ Giresun (n=30) } & \multicolumn{2}{c}{ Toplam (n=62) } \\
\cline { 2 - 7 } & Örnek sayısı & $\mathbf{\%}$ & Örnek sayısı & \% & Örnek sayısı & \% \\
\hline Killi tın & 6 & 18.75 & 14 & 46.67 & 20 & 32.26 \\
Kumlu killi tın & 10 & 31.25 & 8 & 26.67 & 18 & 29.03 \\
Kumlu tın & 6 & 18.75 & 6 & 20 & 12 & 19.35 \\
Killi & 8 & 25 & - & - & 8 & 12.90 \\
Tın & 2 & 6.25 & 2 & 6.67 & 4 & 6.45 \\
\hline
\end{tabular}

Ordu ilinde yer alan fındık bahçelerinden alınan toprak örneklerinin \%18.75'i killi tın, 31.25'i kumlu killi tın, $\% 18.75$ 'i kumlu tın, \%25'i killi ve \%6.25'inin ise tın bünyeli olduğu belirlenmiştir. Giresun'da fındık yetiştiriciliği yapılan bahçelerden alınan toprakların \%46.67'si killi-tın, \%26'sı kumlu killi tın, \%20'si kumlu tın, ve geriye kalan \%6.67'lik kısmının ise tın bünyeli olduğu belirlenmiștir. Her iki ildeki fındık yetiștiriciliği yapılan toprakların bünye sınıfı birlikte değerlendirildiğinde ise toprakların \%87'lik gibi büyük kısmının orta bünyeli olduğu belirlenmiştir (Çizelge 1). Bu bulgular doğrultusunda, Orta ve Doğu Karadeniz bölgesinde yer alan fındık bahçelerinde yürütülen çalışmada benzer sonuçlar elde edilmiş olup bölge topraklarının \%75.3'ünün orta bünyeli olduğu bildirilmiştir (Özyazıcı ve ark., 2016). 
Çizelge 2. Ordu ve Giresun illerindeki fındık bahçelerinden alınan toprak örneklerinin pH, EC, kireç ve organik madde analiz sonuçları

\begin{tabular}{llcccc}
\hline & & \multicolumn{3}{c}{ Bazi kimyasal özellikler } \\
\hline & & pH (1:1) & EC, dS m & Kireç, $\mathbf{0}$ & Organik madde, \% \\
\hline Ordu & Minimum & 5.33 & 0.06 & 1.08 & 1.68 \\
(n=32) & Maksimum & 7.89 & 0.61 & 69.38 & 8.18 \\
& Ortalama & $6.64 \pm 0.8$ & $0.30 \pm 0.1$ & $10.49 \pm 17.9$ & $4.26 \pm 1.7$ \\
Giresun & Minimum & 3.92 & 0.03 & 0.99 & 1.62 \\
(n=30) & Maksimum & 7.03 & 0.87 & 5.80 & 22.42 \\
& Ortalama & $5.73 \pm 0.9$ & $0.42 \pm 0.2$ & $1.99 \pm 0.9$ & $6.84 \pm 5.3$ \\
Toplam & Minimum & 3.92 & 0.03 & 0.99 & 1.62 \\
(n=62) & Maksimum & 7.89 & 0.87 & 69.38 & 22.42 \\
& Ortalama & $6.20 \pm 1.0$ & $0.36 \pm 0.2$ & $6,38 \pm 13,48$ & $5.51 \pm 4.07$ \\
\hline
\end{tabular}

Ordu ilinden örnekleme yapılan toprakların pH değerleri 5.33- 7.89 değerleri arasında olup ortalama değerin 6.64 olduğu belirlenmiștir. Giresun ilinde ise $\mathrm{pH}$ değerleri 3.92-7.03 değerleri arasında olduğu ve ortalama pH değerinin 5.73 olduğu bulunmuştur (Çizelge 2). Elde edilen sonuçlara göre bölge toprakları genel olarak değerlendirildiğinde büyük kısmının hafif asit karakterli olduğu tespit edilmiștir.

Ordu ve Giresun illerindeki fındık bahçelerinden alınan toprak örneklerinin elektriksel iletkenlik (EC) dağılımı sonuçları Çizelge 2'de verilmiştir. Örnekleme yapılan fındık bahçesi topraklarının elektriksel iletkenlik değerleri Ordu ilinde $0.06-0.61 \mathrm{dSm}^{-1}$ arasında olup ortalama elektriksel iletkenlik değerinin 0.30 $\mathrm{dSm}^{-1}$ olduğu bulunmuştur. Giresun ilinde ise 0.03-0.87 $\mathrm{dSm}^{-1}$ aralığında ve ortalama elektriksel iletkenlik değeri $0.42 \mathrm{dSm}^{-1}$ olarak bulunmuştur. Bu sonuçlara göre, Ordu ve Giresun illeri topraklarının tamamı tuzluluk bakımından tuzsuz sınıfında yer aldığı belirlenmiştir.

Ordu ilinde yer alan fındık bahçelerinden alınan toprakların organik madde içerikleri \%1,68-8.18 aralığında olup ortalama \%4.26 olarak bulunmuştur. Giresun ilinde ise organik madde değerleri \%1.62-22.42 değerleri arasında ve ortalama organik madde değeri \%6.84 olarak tespit edilmiştir. Bu sonuçlara göre Ordu ili topraklarının \%78'lik kısmının ve Giresun ili topraklarının ise \%80'lik kısmının organik madde yönünden yeterli olduğu saptanmıştır (Çizelge 2). Elde edilen sonuçlara benzer olarak yapılan çalışmalarda da araştırmacılar, yöre topraklarının asit karakterli, tuz içeriği bakımından düşük, az kireçli ve yeterli seviyede organik maddeye sahip olduğunu belirlemişlerdir (Tarakçığlu ve ark., 2003; Özkutlu ve ark., 2016).

Çizelge 3. Ordu ve Giresun illerindeki fındık bahçelerinden alınan toprak örneklerinin biyolojik analiz sonuçları

\begin{tabular}{|c|c|c|c|c|c|c|c|c|c|}
\hline & \multicolumn{3}{|c|}{ Ordu } & \multicolumn{3}{|c|}{ Giresun } & \multicolumn{3}{|c|}{ Ordu + Giresun } \\
\hline Özellik & Min. & Maks. & Ort. & Min. & Maks. & Ort. & Min. & Maks. & Ort. \\
\hline $\mathrm{CO}_{2}{ }^{1}$ & 0.04 & 0.23 & $0.12 \pm 0.1$ & 0.04 & 0.31 & $0.11 \pm 0.1$ & 0.04 & 0.31 & $0.12 \pm 0.1$ \\
\hline $\mathrm{MBC}^{2}$ & 13.73 & 80.28 & $58.24 \pm 14.6$ & 7.51 & 72.66 & $40.76 \pm 18.3$ & 7.51 & 80.28 & $49.78 \pm 18.6$ \\
\hline $\mathrm{DHA}^{3}$ & 0.06 & 2.01 & $0.52 \pm 0.4$ & 0.20 & 1.44 & $0.42 \pm 0.3$ & 0.06 & 2.01 & $0.47 \pm 0.4$ \\
\hline $\mathrm{KA}^{4}$ & 42.77 & 141.31 & $80.98 \pm 28.4$ & 68.81 & 347.59 & $168.75 \pm 75.9$ & 42.77 & 347.59 & $123.45 \pm 72.1$ \\
\hline
\end{tabular}

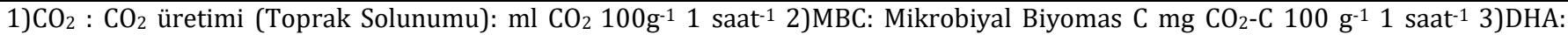
Dehidrogenaz aktivitesi, $\mu \mathrm{g}$ TPF g-1 24 saat $^{-1}$ 4)KA: Katalaz aktivitesi, $\mathrm{ml} \mathrm{O}_{2} \mathrm{1g}^{-1} 3$ dak $^{-1}$

Toprak solunumu, toprak karbon döngüsünün temel bir bileşenini temsil etmekte olup (Raich ve Schlesinger, 1992) toprakta karbon depolanmasının, toprak biyolojik aktivitesinin ve genel toprak kalitesinin bir göstergesidir (Ewel ve ark. 1987; Tufekcioglu ve ark. 2001). Genel olarak, toprak solunumu bitki köklerinin ve toprak mikroorganizmalarının solunumuna bağlıdır. Toprak sıcaklığı ve toprak nemi gibi çevresel faktörlerin, toprak solunumunun mevsimsel dinamikleri üzerinde belirgin bir etkisi olduğu bilinmektedir (Lloyd ve Taylor 1994). Tekstür, organik madde içeriği, kök yoğunluğu ve mikrobiyal biyokütle gibi toprağın fiziksel ve kimyasal özellikleri ayrıca toprak solunumunun büyüklüğünü de etkilediği bildirilmiştir (Haynes ve Gower, 1995; Kelting ve ark., 1998; Raich ve Tufekcioglu, 2000).

Ordu ilindeki fındık bahçelerinden alınan toprakların $\mathrm{CO}_{2}$ üretimi miktarları 0.04-0.23 ml CO $2100 \mathrm{~g}^{-1} 1$ saat- $^{-1}$ aralığında olup ortalama $\mathrm{CO}_{2}$ üretim değeri $0.12 \mathrm{ml} \mathrm{CO}_{2} 100 \mathrm{~g}^{-1} 1$ saat $^{-1}$ olarak belirlenmiştir. Giresun ilindeki toprakların $\mathrm{CO}_{2}$ üretimi $0.04-0.23 \mathrm{ml} \mathrm{CO}_{2} 100 \mathrm{~g}^{-1} 1$ saat-1 $^{-1}$ değerleri arasında olup ortalama $0.12 \mathrm{ml} \mathrm{CO}_{2} 100 \mathrm{~g}^{-1}$ 1 saat $^{-1}$ olarak belirlemiştir (Çizelge 3).

Mikrobiyal biyomas karbon, toprağın mikrobiyal popülasyonunun toplam kütlesinin belirlenmesinde mikroskop veya diğer yöntemlere göre çok daha kolay ve hızlı olması, organik maddenin parçalanmasına etkisi (Powlson ve Brookes, 1987) ve toprakta besin döngüsünün sağlanması açısından önemli olduğu bildirilmiştir (Jenkinson ve Parry, 1989). 
Ordu ilinde yer alan fındık bahçelerinden alınan toprakların mikrobiyal biyomas karbon miktarları 13.73$80.28 \mathrm{mg} \mathrm{MBC} 1 \mathrm{~g}^{-1} \mathrm{kuru}$ toprak 1 saat $^{-1}$ değerleri arasında ve ortalama mikrobiyal biyomas karbon miktarı $58.14 \mathrm{mg} \mathrm{MBC} 1 \mathrm{~g}^{-1}$ kuru toprak $1 \mathrm{saat}^{-1}$ olarak hesaplanmıştır. Giresun ilinde ise 7.51-72.66 mg MBC $1 \mathrm{~g} \mathrm{~g}^{-1}$ kuru toprak 1 saat $^{-1}$ değerleri aralığında olup ortalama mikrobiyal biyomas karbon miktarı 40.76 mg MBC 1 $\mathrm{g}^{-1}$ kuru toprak 1 saat $^{-1}$ olduğu belirlenmiştir (Çizelge 3 ).

Dehidrogenaz enzimi tüm canlı mikrobiyal hücrelerde hücre içinde oluştukları için (Salazar ve ark., 2011) toprağın genel mikrobiyal aktivitesinin bir göstergesi olarak kullanılırlar (Zhao ve ark., 2010). Ayrıca, dehidrogenaz enzimi toprakta organik substratlardan organik alıcılara hidrojen transfer ederek toprak organik maddesinin biyolojik oksidasyonunda önemli bir oynar (Zhang ve ark., 2010).

Topraklarda yapılan dehidrogenaz enzim aktivitesi sonucuna göre Ordu ilinden alınan toprak örneklerinin dehidrogenaz enzim aktivitesi 0.06-2.01 $\mu \mathrm{g}$ TPF g-1 24 saat $^{-1}$ değerleri arasında ve ortalama aktivite değeri $0.52 \mu \mathrm{g}$ TPF g- ${ }^{-1} 24$ saat $^{-1}$ olarak belirlenmiştir. Giresun ili dehidrogenaz enzim aktivitesi 0.20-1.44 $\mu \mathrm{g}$ TPF $\mathrm{g}^{-1}$ 24 saat $^{-1}$ değerleri arasında bulunmuş ve ortalama $0.42 \mu$ TPF g-1 $^{-1} 24$ saat $^{-1}$ olarak belirlenmiştir (Çizelge 3 ).

Katalaz enzimi $\left(\mathrm{H}_{2} \mathrm{O}_{2}: \mathrm{H}_{2} \mathrm{O}_{2}\right.$-oxidoreductase, EC 1.11.1.6.), hidrojen peroksitin $\left(\mathrm{H}_{2} \mathrm{O}_{2}\right)$, su ve moleküler oksijene parçalanma reaksiyonunu katalizleyen bir enzimdir. Katalaz enzim aktivitesi, topraktaki aerobik mikrobiyal popülasyonun varlığı ve toprakların verimliliği ile yakından ilişkili olup, intrasellüler yani hücre içi bir enzim olan katalaz enzim tayini toprakta mevcut aerobik mikroorganizma popülasyonunun değerlendirilmesinde indikatör olarak kullanılır (Garcia ve Hernandez, 1997). Hidrojen peroksit $\left(\mathrm{H}_{2} \mathrm{O}_{2}\right)$, canlı organizmaların solunum süreçlerinde ve organik maddenin oksidasyona uğradığı çeşitli biyokimyasal süreçler sonunda oluşmaktadır (Weetall ve ark.,1965; Trevors, 1984).

Fındık bahçelerinden alınan toprak örneklerinin katalaz enzim aktivitesi değerleri Ordu ilinde 42.77-141.31 $\mathrm{ml} \mathrm{O}_{2} \mathrm{~g}^{-1} 3$ dak $^{-1}$ değerleri arasında olup ortalama katalaz enzim aktivitesi değeri $159.36 \mathrm{ml} \mathrm{O}_{2} \mathrm{~g}^{-1} 3$ dak $^{-1}$ olarak belirlenmiştir. Giresun ilinden alınan toprak örneklerinin katalaz enzim aktivitesi değerlerinin 68.61$347.59 \mathrm{ml} \mathrm{O}_{2} \mathrm{~g}^{-1} 3$ dak $^{-1}$ aralığında ve ortalama katalaz enzim aktivitesi değerinin ise $168.75 \mathrm{ml} \mathrm{O}_{2} \mathrm{~g}^{-1} 3$ dak $^{-1}$ olduğu tespit edilmiştir (Çizelge 3).

Fındık bahçelerinden alınan toprakların bazı kimyasal özellikleri ile biyolojik özellikleri arasındaki ilişskilerinin belirlenmesi amacıyla SPSS.17 paket programında korelasyon analizi yapılmıştır. Fındık bahçesi topraklarının bazı kimyasal özellikleri ve biyolojik özellikleri arasındaki lineer korelasyon katsayıları (r) Çizelge 4'te verilmiştir.

Çizelge 4. Fındık bahçesi topraklarının bazı biyolojik özellikleriyle kimyasal özellikleri arasındaki korelasyonlar.

\begin{tabular}{lcccc}
\hline $\mathrm{n}=62$ & $\mathbf{C O}_{2}$ & MBC & DHA & KA \\
\hline CO2 & 1 & $0.387^{* *}$ & $0.399^{* *}$ & 0.246 \\
MBC & $0.387^{* *}$ & 1 & 0.172 & -0.210 \\
DHA & $0.399^{* *}$ & 0.172 & 1 & 0.126 \\
KA & 0.246 & -0.210 & 0.126 & 1 \\
pH & $0.334^{* *}$ & $0.275^{*}$ & 0.225 & $-0.412^{* *}$ \\
EC & -0.076 & $-0.380^{* *}$ & -0.071 & 0.171 \\
OM & 0.028 & 0.108 & -0.075 & $0.396^{* *}$ \\
CaCO3 & $0.388^{* *}$ & 0.231 & $0.378^{* *}$ & -0.157 \\
\hline
\end{tabular}

Toprak örneklerinin pH değerleri ve kireç içeriğiyle $\mathrm{CO}_{2}$ üretimi arasında istatistiki açıdan 0.01 önem düzeyinde pozitif ilişkiler olduğu tespit edilmiştir. Toprakların $\mathrm{CO}_{2}$ üretim miktarlarılyla diğer biyolojik özelliklerinden mikrobiyal biyomas karbon miktarı ve dehidrogenaz enzim aktivitesi ile pozitif ilişkiler belirlenmiş olup, bu ilişkilerden 0.01 önem düzeyinde anlamlı ilişkiler olduğu belirlenmiştir (Çizelge 4).

Fındık bahçesi topraklarının mikrobiyal biyomas karbon miktarının elektriksel iletkenlik değerleri ile arasında negatif ve toprak reaksiyonu $(\mathrm{pH})$ ile arasında ise pozitif ilişki olduğu belirlenmiştir. Bu ilişkilerden toprak reaksiyonunun 0.05 önem düzeyinde ve elektriksel iletkenlik değerinin ise 0.01 önem düzeyinde olduğu yapılan korelasyon analizi ile belirlenmiştir (Çizelge 4).

Elde ettiğimiz verilere benzer olarak Skujins (1973) yaptığı çalışmada mikroorganizma sayısı ile dehidrogenaz enzim aktivitesinin ve $\mathrm{CO}_{2}$ üretimi arasında önemli ilişkiler olduğunu belirlemiş fakat bu ilişskinin sürekli olarak gerçekleșmediğini bildirmiştir. Wang ve ark. (2018) topraklara ilave edilen azotlu gübrelerin uzun vadede bakteri popülasyonunu azalttığını belirlemişlerdir. Bunun yanı sıra düşük pH ve yüksek elektriksel iletkenlik değerleri ve amonyum konsantrasyonları gibi yoğunlaşmış çevresel streslerde 
yine fazla miktarda azot girdilerinde topraklarda mevcut olan mantarlardan ziyade bakterileri engelleyen bir mekanizma olabileceğini bildirmişlerdir.

Yapılan korelasyon analiz sonuçları incelendiğinde, toprakların dehidrogenaz enzim aktiviteleri ile kireç içeriği arasında pozitif ilişki olduğu belirlenmiş olup bu ilişkinin istatistiki açıdan 0.01 önem düzeyinde anlamlı olduğu belirlenmiştir. Dehidrogenaz enzim aktivitesi üzerine kireç miktarındaki artışın ve buna bağlı olarak pH artışlarının olumlu etkiler gösterebileceği anlaşılmaktadır (Çizelge 4).

Elde edilen sonuçlara benzer olarak, toprak dehidrogenaz aktivitesi ile pH arasında anlamlı pozitif korelasyonlar bulunduğunu, asit koşulların potansiyel enzim aktivitesini baskıladığı yapılan çalışmalarda bildirilmiştir (Frankenberger ve Johanson, 1982; Levyk ve ark. 2007; Fernández-Calviño ve ark., 2010). Aynı zamanda maksimum dehidrogenaz aktivitesinin nötr ve hafif alkali toprak şartlarında meydana gelebileceği yapılan çalışmalarla bildirilmiştir (Trevors, 1984; Włodarczyk ve ark., 2002; Ros ve ark., 2003).

Fındık bahçesi topraklarının katalaz enzim aktivitesi ile toprakların kimyasal özelliklerinden pH değerleri ve organik madde içeriği arasında istatistiki açıdan (0.01) önemli ilişkiler olduğu belirlenmiştir. Bu ilişkilerden pH değerinin negatif, organik madde içeriğinin ise pozitif yönde olduğu belirlenmiştir (Çizelge 4).

Elde ettiğimiz verilere benzer olarak Gür (1987), organik madde kapsamının katalaz enzim aktivitesi ile yakından ilişkili olduğunu, alkali ve kireçli topraklarda daha yüksek katalaz enzim aktivitesinin meydana geldiğini belirtmiştir.

\section{Sonuç ve Öneriler}

Ordu ve Giresun illerinde fındık yetiştiriciliği yapılan alanlardan alınan toprakların fiziksel, kimyasal ve biyolojik özellikleri belirlenerek bunların birbirleri arasındaki ilişkiler değerlendirilmiştir. Yapılan toprak analiz sonuçlarına göre, Ordu ve Giresun yöresinde fındık yetiştirilen topraklar genel olarak; orta bünyeli, asidik reaksiyonlu, tuzsuz, kireçsiz, yeterli organik madde içeriğine sahip olduğu belirlenmiştir. Korelasyon analizine göre ise, toprakların biyolojik özellikleri ile toprak reaksiyonu, elektriksel iletkenlik, kireç içeriği ve organik madde arasında istatistiksel açıdan önemli ilişkiler saptanmıştır. Toprak pH'sı ile toprak solunumu ve mikrobiyal biyomas $\mathrm{C}$ arasında önemli pozitif, toprak pH'sı ile katalaz enzim aktivitesi ile arasında negatif, elektriksel iletkenlik ile mikrobiyal biyomas C arasında negatif, kireç içeriği ile dehidrogenaz enzim aktivitesi arasında pozitif ve organik madde ile katalaz enzim aktivitesi arasında pozitif ilişkiler olduğu belirlenmiştir.

Sonuç olarak, yöre topraklarının en temel sorunlarından biri olan düşük pH değerlerinin optimum düzeye getirilmesi için gerekli uygulamaların yapılması ile toprakların biyolojik aktivitesi de optimum düzeye getirilebilir. Kireçleme ve alkalen karakterli gübre uygulamalarının yapılması bu sorunu ortadan kaldırmaya yönelik önlemlerin başında gelmektedir. Genel olarak toprakların organik madde seviyesi yapılan çalışmada yeterli seviyede olmasına rağmen organik madde içeriğinin toprakların sürdürülebilirliği, toprak kalitesi ve canlılığı açısından çok önemli bir parametre olduğu için muhafaza edilmesi gerekli görülmektedir.

\section{Teşekkür}

Bu çalışma, Abdurrahman Ay’ın Yüksek Lisans Tez çalışmasından üretilmiştir. Çalışmanın yürütülmesinde destek olan Ondokuz Mayıs Üniversitesi'ne teșekkür ederiz

\section{Kaynaklar}

Anderson JP, 1982. Soil respiration. Methods of soil analysis. Part 2. Chemical and microbiological properties, page, A.L. (Ed.) ASA-SSSA, Madison, Wisconsin, USA. pp 831-871.

Anderson JPE, Domsch KH, 1978. A physiological method for the quantitative measurement of microbial biomass in soils. Soil Biology and Biochemistry, 10(3): 215-221.

Anonim 2017. Kooperatifçilik Genel Müdürlügü $\quad$ Türkiye $\quad$ Fındık Raporu. http://koop.gtb.gov.tr/data/5ad06bb9ddee7dd8b423eb23/2017\%20F\%C4\%B1nd\%C4\%B1k\%20Raporu.pdf(Erişim: tarihi: 06.05.2019).

Beck TH, 1971. Die messung der katalaseaktivitaet von Böden. Zeitschrift für Pflanzenernährung und Bodenkunde, $130(1), 68-81$.

Cusack DF, Silver WL, Torn MS, Burton, SD, Firestone MK, 2011. Changes in microbial community characteristics and soil organic matter with nitrogen additions in two tropical forests. Ecology, 92(3), 621-632. 
Durmuş M, Erkoçak A, Kızılkaya R, Dengiz 0, 2011. Alüviyal Araziler Üzerinde Oluşan Farklı Toprakların Katalaz Enzim Aktivitelerindeki Değişimin Belirlenmesi. Toprak ve Su Sempozyumu. 25-27 Mayıs, Ankara, 153-159.

Ewel KC, Cropper WP, Gholz HL, 1987. Soil CO2 evolution in Florida slash pine plantations. I. Changes through time. Canadian Journal of Forest Research, 17(4), 325-329.

Fernández-Calviño D, Soler-Rovira P, Polo A, Díaz-Raviña M, Arias-Estévez M, Plaza C, 2010. Enzyme activities in vineyard soils long-term treated with copper-based fungicides. Soil Biology and Biochemistry, 42(12), 21192127.

Frankenberger Jr WT, Johanson JB, 1982. Effect of pH on enzyme stability in soils. Soil Biology and Biochemistry, 14(5), 433-437.

Garcia C, Hernández T, 1997. Biological and biochemical indicators in derelict soils subject to erosion. Soil Biology and Biochemistry, 29(2), 171-177.

Gür K, 1987. Toprak Biyolojisi Ders Notları. Selçuk Üniversitesi Ziraat Fakültesi Yayınları 10, Konya.

Haynes BE, Gower ST, 1995. Belowground carbon allocation in unfertilized and fertilized red pine plantations in northern Wisconsin. Tree physiology, 15(5), 317-325.

Jenkinson DS, Parry LC, 1989. The nitrogen cycle in the Broadbalk wheat experiment: a model for the turnover of nitrogen through the soil microbial biomass. Soil Biology and Biochemistry, 21(4), 535-541.

Jones, JB 2001. Laboratory guide for conducting soil tests and plant analysis. Crc. doi:

$10.1201 / 9781420025293$

Karaca A, Kızılkaya R, Horuz H, Arcak S, 1998. Fındık tarımı yapılan toprakların biyokimyasal aktivite özellikleri ile toprak özellikleri arasındaki ilişkiler. Pamukkale Üniversitesi Mühendislik Fakültesi Mühendislik Bilimleri Dergisi, 4(5), 813-822.

Karadeniz T., Bostan S. Z., Tuncer C, Tarakçıoğlu C, 2008. Fındık yetiştiriciliği. Ordu Ziraat Odası Başkanlığı Bilimsel Yayınlar Serisi No:1, 154, Ordu.

Kelting DL, Burger JA, Edwards GS, 1998. Estimating root respiration, microbial respiration in the rhizosphere, and root-free soil respiration in forest soils. Soil Biology and Biochemistry, 30(7), 961-968.

Kızılkaya R, Arcak S, Horuz A, Karaca A, 1998. Çeltik Tarımı Yapılan Toprakların Enzim Aktiviteleri Üzerine Toprak Özelliklerinin Etkisi. Pamukkale Üniversitesi Mühendislik Bilimleri Dergisi, 4(3), 797-804.

Kızılkaya R, Dede V, Dengiz O, Ay A, 2019. Ilgaz dağlarında farklı periglasyal şekiller üzerinde oluşmuş topraklara ait özelliklerin dehidrogenaz enzim aktivitesine etkisi. Toprak Bilimi ve Bitki Besleme Dergisi, 7(2), 121-127.

Köksal İ, 2002. Türk Fındık Çeşitleri. Fındık Tanıtım Grubu Yayınları, Ankara. 136s.

Levyk V, Maryskevych O, Brzezińska M, Włodarczyk T, 2007. Dehydrogenase Activity of Technogenic Soils of Former Sulphur Mines (Yvaoriv and Nemyriv, Ukraine). International Agrophysics, 21(3), 255.

Lloyd J, Taylor JA, 1994. On the temperature dependence of soil respiration. Functional ecology, 315-323.

Lu X, Mo J, Gilliam FS, Zhou G, Fang Y, 2010. Effects of experimental nitrogen additions on plant diversity in an oldgrowth tropical forest. Global Change Biology, 16(10), 2688-2700.

Matson PA, McDowell WH, Townsend AR, Vitousek PM, 1999. The globalization of N deposition: ecosystem consequences in tropical environments. Biogeochemistry, 46(1-3), 67-83.

Özbek S, 1978. Fındık Yetiştiriciliği. Özel Meyvecilik. Çukurova Üniversitesi Ziraat Fakültesi Yayınları, No:128, 286-321, Adana.

Özkutlu F, Korkmaz K, Özenç N, Aygün A, Şahin Ö, Kahraman M, Ete Ö, Taşkın B, 2016. Ordu-Merkez ilçedeki bazı fındık bahçelerinin mineral beslenme durumunun belirlenmesi. Akademik Ziraat Dergisi, 5(2), 77-86.

Özyazıcı, MA, Dengiz O, Aydoğan M, Bayraklı B, Kesim E, Urla Ö, Yıldız H, Ünal E, 2016. Orta ve Doğu Karadeniz Bölgesi tarım topraklarının temel verimlilik düzeyleri ve alansal dağılımları. Anadolu Tarım Bilim Dergisi, 31.

Parr JF, Papendick RI, 1997. Soil quality: relationships and strategies for sustainable dryland farming systems. Annals of Arid Zone, 36(3), 181-191.

Pepper IL, Gerba CP, Brendecke JW, 1995. Environmental Microbiology: A Laboratory Manual. Academic Press Inc. New York, USA

Phoenix GK, Hicks WK, Cinderby S, Kuylenstierna JCI, Stock WD, Dentener FJ, Giller KE, Austin AT, Lefroy RDB, Gimeno BS, Ashmore MR, Ineson P, 2006. Atmospheric nitrogen deposition in world biodiversity hotspots: the need for a greater global perspective in assessing $\mathrm{N}$ deposition impacts. Global Change Biology, 12(3), 470-476.

Powlson DS, Prookes PC, Christensen BT, 1987. Measurement of soil microbial biomass provides an early indication of changes in total soil organic matter due to straw incorporation. Soil biology and biochemistry, 19(2), $159-164$.

Raich JW, Schlesinger WH, 1992. The global carbon dioxide flux in soil respiration and its relationship to vegetation and climate. Tellus B, 44(2), 81-99.

Raich JW, Tufekcioglu A, 2000. Vegetation and soil respiration: Correlations and controls. Biogeochemistry, 48(1), 7190.

Ros M, Hernandez MT, García C, 2003. Soil microbial activity after restoration of a semiarid soil by organic amendments. Soil Biology and Biochemistry, 35(3), 463-469.

Rowell DL, 1996. Soil science: methods and applications. 3rd Edition Longman. London,

UK. 
Salazar S, Sánchez LE, Alvarez J, Valverde A, Galindo P, Igual JM, Peix A, Santa-Regina I, 2011. Correlation among soil enzyme activities under different forest system management practices. Ecological Engineering, 37(8), 11231131.

Skujins J, 1973. Dehydrogenase: an indicator of biological activities in arid soils. Bulletins from the Ecological Research Committee, (17), 235-241.

Smith J L, Halvorson JJ, Papendick RI, 1993. Using multiple-variable indicator kriging for evaluating soil quality. Soil Science Society of America Journal, 57(3), 743-749.

Tarakçıoğlu C, 2001. Ordu Yöresinde Yetiştirilen Fındık (Corylus Avellana L.) Bitkisinin Beslenme Durumunun Toprak ve Bitki Analizleriyle Belirlenmesi ve Fındık Meyvesinin Bazı Kalite Özellikleri. Doktora Tezi, Ankara Üniversitesi Fen Bilimleri Enstitüsü Toprak Anabilim Dalı, 185, Ankara.

Trevors JT, 1984a. Effect of substrate concentration, inorganic nitrogen, 02 concentration, temperature and pH on dehydrogenase activity in soil. Plant and Soil, 77(2-3), 285-293.

Trevors JT, 1984b. Rapid gas chromatographic method to measure H2O2 oxidoreductase (catalase) activity in soil. Soil biology and biochemistry.

Tufekcioglu A, Raich JW, Isenhart TM, Schultz RC, 2001. Soil respiration within riparian buffers and adjacent crop fields. Plant and Soil, 229(1), 117-124.

Wang C, Lu X, Mori T, Mao Q, Zhou K, Zhou G, Nie Y, Mo J, 2018. Responses of soil microbial community to continuous experimental nitrogen additions for 13 years in a nitrogen-rich tropical forest. Soil Biology and Biochemistry, 121, 103-112.

Weetall HH, Weliky N, Vango SP, 1965. Detection of Micro-Organisms in Soil by Their Catalatic Activity. Nature, 206(4988), 1019.

Włodarczyk T, Stępniewski W, Brzezińska M, 2002. Dehydrogenase activity, redox potential, and emissions of carbon dioxide and nitrous oxide from Cambisols under flooding conditions. Biology and Fertility of Soils, 36(3), 200206.

Yurtsever N, 1984. Deneysel istatistik metodları. Tarım, Orman ve Köyişleri Bakanlı̆̆ı. Köy Hizmetleri Genel Müdürlüğü Yayınları, Ankara. s.623.

Zhang N, Xing-Dong H, Yu-Bao G, Yong-Hong L, Hai-Tao W, Ma D, Zhang R, Yang S, 2010. Pedogenic carbonate and soil dehydrogenase activity in response to soil organic matter in Artemisia ordosica community. Pedosphere, 20(2), 229-235.

Zhao B, Chen J, Zhang J, Qin S, 2010. Soil microbial biomass and activity response to repeated drying-rewetting cycles along a soil fertility gradient modified by long-term fertilization management practices. Geoderma, 160(2), 218224. 